\title{
ПРОБЛЕМА ВДОСКОНАЛЕННЯ ЮРИДИЧНОЇ ТЕХНІКИ ПРИРОДООХОРОННОГО ЗАКОНОДАВСТВА УКРАЇНИ
}

Патлачук О. В.

\begin{abstract}
У статmі розглянуто пропозиції з удосконалення юридичної техніки до Закону «Про охорону навколишнього середовища» та кодифікованих актів, які регламентують охорону водних об'єктів, природно-заповідний і лісовий фонд України. Внесено пропозиції стосовно закріплення прав громадян на безпечне природне середовище, на можливі звернення до органів держаної влади та місцевого самоврядування. Звертається увага на необхідність включення до змісту кодифікованих актів преамбул і принципів права, які повинні забезпечити ефективне використання природних ресурсів.
\end{abstract}

Ключові слова: природоохоронне законодавство, юридична техніка, органи державної влади, права людини, принципи права, термінологія.

В статье рассмотрены предложения по совершенствованию юридической техники в Закон «Об охране окружающей среды» и кодифицированных актов, регламентирующих охрану водных объектов, природно-заповедный и лесной фонд Украины. Внесены предложения касательно закрепления прав граждан на безопасную среду, на возможные обращения в органы государственной власти и местного самоуправления. Обращается внимание на необходимость включения в содержание кодифицированных актов преамбулы и принципов права, которые должны обеспечить эффективное использование природных ресурсов.

Ключевые слова: природоохранное законодательство, юридическая техника, органы государственной власти, права человека, принципы права, терминология.

The article discusses the proposals for improving the legal machinery of the Law "On environmental protection" and codified acts regulating the protection of water bodies, natural reserves and forest Fund of Ukraine. Proposals to consolidate the rights of citizens to a safe environment, the potential appeal to the state authorities and local self-government. Attention is drawn to the need to include in the content of the codified acts of the preambles and principles of law, which must ensure efficient use of natural resources.

It is proposed to amend article 9 of the basic law "On the protection of the environment, and to provide public organizations the right to establish conservation funds without the consent of the local public authorities. To Supplement the Water Code of Ukraine, Forest Code of Ukraine", the Law "About plant world" with preambles in which to fix the aim, the objectives of codification of the acts and to put them in the principles of law which constitute the fundamental principles on which the regulation of the use and protection of water objects, forests and fauna and supports the implementation of requirements of legal technique on the specific normative regulation.

It is proposed to implement the requirement of legal technology as an integrated approach by amending the Law "On Nature reserve Fund of Ukraine" articles that outline the basics of the development of the NRF and to include in its content the need to prepare national regional programmes for the creation of such objects. Based on this, requirements of legal tech-

Патлачук О. В., 2019 nique to the Forest Code being proposed for inclusion in article 1 of the basic concept of the reproduction of forests, forest products, natural replenishment, thus avoiding duplication and the need for the use of Banquet standards.

Key words: environmental legislation, legal technique, the bodies of state power, human rights, principles of law terminology.

Постановка проблеми та їі актуальність. Актуальність теми дослідження пов'язана 3 необхідністю вдосконалення юридичної техніки природоохоронного законодавства, яке не в змозі надійно захистити природні ресурси України від різного роду правопорушень. Одним зі шляхів вирішення цієї проблеми є удосконалення техніко-юридичної якості законодавства у цій сфері з метою запобігання колізіям, дефектам, прогалинам та інших вадам нормативно-правових актів. Натепер юридична техніка $€$ складним інститутом, в який входять методи, засоби та інші інструментарії практичної діяльності з підготовки нормативно-правових актів.

Природоохоронне законодавство України характеризується наявністю багатьох декларативних понять і термінів, багатозначущих нормативних формулювань, нечітким визначенням прав та обов'язків суб'єктів, наявністю значної кількості бланкетних норм. Такий стан речей вимагає використання юридичної техніки, яка дозволить дати конкретні рекомендації щодо вдосконалення правової галузі. Виходячи з цього, доцільно на підставі дослідження кодифікованих актів, прийнятих у цій сфері, розробити шляхи використання досягнень юридичної техніки з метою їх удосконалення.

Аналіз останніх досліджень і публікацій показує наявність двох блоків літератури: а) досліджень у сфері природоохоронного права; б) розробки, які торкаються питань юридичної техніки. До першої групи належить праці А.П. Гетьмана, Ю.С. Шемшученко, В.В. Костицького, В.І. Андрейцева, В.Л. Мунтяна, В.В. Петрова, Ю.І. Ляпунова. Другий блок складається із розробок І.Д. Шутака, І.І. Онищука, Ж.О. Дзейко, В.М. Баранова, В.К. Бабаєва, В.Н. Карташова, Г.І. Муромцева, А.С. Піголкіна, Ю.А. Тихомирова, М.Л. Давидової, T.В. Кошаніної та інших. Незважаючи на наявність цих праць, питання юридичної техніки природоохоронного законодавства розглядалися побіжно у зв'язку з розглядом більш загальних питань, тому ця проблема потребує своєї подальшої розробки та систематизації.

Метою статті $є$ розробка пропозицій щодо удосконалення юридичної техніки кодифікованих актів, присвячених водному законодавству, охороні лісів і природно-заповітному фонду.

Виклад основних матеріалів дослідження необхідно розпочати з розгляду концепції удосконалення юридичної техніки природоохоронного законодавства, яка включає низку аспектів: усунення причин і умов, 


\section{Проблеми \\ екологічного законодавства}

які сприяють формуванню дефектів, їх виявлення та усунення; виділення та реалізація умов, які забезпечують високу ефективність юридичної техніки. При розгляді цих аспектів необхідно зазначити, що причини низької ефективності юридичної техніки поділяються на дві групи: об'єктивні та суб'єктивні. На думку С.С. Алексєєва, під об'єктивними причинами розуміють ті, які не залежать від волі та свідомості законодавця [1, с. 14]. Стосовно природоохоронного права необхідно зазначити, що природні об'єкти існують за власними законами, які треба враховувати при їх використанні. У своїй діяльності люди можуть втручатися у процес розвитку природних явищ, але вони не спроможні повністю змінити закони їх функціонування. Тому необхідна діяльність у сфері проведення моніторингу природних об'єктів, що включає в себе систематичні спостереження за станом довкілля та техногенними об'єктами, які впливають на нього.

Суб'єктивні причини визначаються особливостями суб'єктів екологічних відносин: нечіткий розподіл компетенцій між суб'єктами правотворчості, відсутність комплексного планування, використання та охорона природних об'єктів, недосконалість організаційної роботи в процесі підготовки та прийняття нормативно-правових актів, недостатній рівень екологічних і правових знань. В Україні спостерігається тенденція постійних змін прав, повноважень та обов'язків центрального органу виконавчої влади в сфері охорони природи. Цілком зрозуміло, що ці причини тісно пов'язані між собою, дублюють і впливають одна на одну.

На думку Н.А. Власенко, при дослідженні причин дефектів юридичної техніки необхідно виходити 3 двох факторів: специфіки фактичних відносин, які підпадають під правову регламентацію, та особливостей правотворчості [2, с. 24]. Специфіка таких відносин пов'язана з тим, що при розгляді юридичної техніки необхідно виходити з того, що природоохоронне право діє в системі «природа-суспільство», практичним результатом такої взаємодії $\epsilon$ та обставина, що при прийнятті нормативно-правових актів необхідно враховувати взаємовплив цих складників. У таких умовах різко зростає роль юридичної техніки, яка, на думку А.С. Піголкина, повинна забезпечити найкращі умови підготовки нормативно-правових актів при тому, що їх зміст характеризується конкретністю, логічністю викладення, ясністю [3, с. 24-27].

Виходячи з цих теоретичних установ, доцільно надати пропозиції щодо удосконалення юридичної техніки в сфері використання та охорони природних об'єктів. Основним законом, який регламентує діяльність у цій сфері, $\epsilon$ ЗУ «Про охорону навколишнього природного середовища» 1991 року. Натепер особливе значення надається моделі закріплення прав громадян на безпечне природне середовище, яке $є$ своєрідним індикатором відповідності законодавчого акту, сучасному стану науки, міжнародним нормам та угодам, які були ратифіковані Верховною Радою. Так, ст. 9 Закону України «Про охорону навколишнього природного середовища» містить перелік екологічних прав громадян України: право на безпечне для життя і здоров'я навколишнє природне середовище; участь в обговоренні та внесення пропозицій до проектів нормативно-правових актів, розміщення, будівництво і реконструк- ція об'єктів, які можуть негативно впливати на стан довкілля; внесення пропозицій до органів державної влади й органів місцевого самоврядування.

Така диспозиція потребує свого доповнення у вигляді надання держаних гарантій, прав громадян на безпечне навколишнє середовище та охорону їх здоров'я від несприятливих впливів. Як вказує О.В. Толкаченко, у державах-членах ЄС використовується модель закріплення таких прав безпосередньо у конституціях. До таких країн належить Бельгія, Іспанія, Португалія та Фінляндія [4, с. 177]. А.П. Гетьман і В.В. Костицький звертають увагу на наявність тенденцій у розвитку природоохоронного законодавства на національному рівні через формування законів комплексного характеру, згідно чого відбувається розвиток українського права у цій сфері [5, с. 76].

Юридична техніка дозволяє уникнути дефектів нормативно-правових актів, пов'язаних з обсягом і характером компетенцій структур, які мають право контролю в сфері використання та охорони природних об'єктів. Враховуючи важливу роль громадських організацій та об'єднань, удосконалення потребують статті цього закону, пов'язані повноваженнями та правами громадські об'єднання та громадської екологічної експертизи, громадського контролю у галузі охорони навколишнього природного середовища. 3 цієї точки зору необхідно внести доповнення до ст. 21 «Повноваження громадських організацій у галузі охорони навколишнього природного середовища».

Громадські природоохоронні організації мають право брати участь у розробці планів, програм; у проведенні перевірок виконання підприємствами, установами та організаціями природоохоронних планів і заходів; вільного доступу до екологічної інформації; на підготовку пропозицій про організацію територій та об'єктів ПЗФ; подавати до суду позови про відшкодування шкоди. Тому доцільно внести доповнення до п. А ст. 21, в якій варто зафіксувати право громадських організацій надавати конкретні пропозиції щодо планів і програм, пов'язаних з охороною природи, а в разі їх неврахування отримувати обґрунтовані пояснення.

При розгляді п. Б ст. 21, на думку автора, не доцільним $є$ положення закону стосовно необхідності погодження створення громадських фондів охорони природи з місцевими радами. Причиною такого підходу $є$ практика того, що здебільшого інтереси громад і місцевих рад не співпадають між собою. Прикладом таких конфліктів $є$ практика діяльності місцевих рад стосовно виділення земельних ділянок вздовж річок, морів, водосховищ, озер, що значно порушує природний баланс таких об'єктів.

П. В ст. 21 необхідно доповнити положенням закону стосовно того, що громадські організації повинні мати право підготовки окремого документу при проведенні перевірок виконання підприємствами, установами та організаціями природоохоронних планів і заходів. Розгляд п. Д ст. 21 показує необхідність доповнення цього положення закону стосовно оприлюднення екологічної інформації за допомогою соціальних мереж та інтернету, в яких повинна міститься інформація щодо об'єктів, які планують будувати, а також можливий негативний вплив на природне середовище. Як вказує О.Л. Дубовик, екологічна інформація дає можливість чітко виділити характеристики природних об'єктів, 
дозволяє виявити логічні зв'язки відношення з іншими поняттями природоохоронного законодавства [6, с. 7].

Натепер реальністю українського природоохоронного права $\epsilon$ наявність значної кількості законних і підзаконних актів, що призводить до появи дефектів юридичної техніки. У такій ситуації, на думку І.А. Ігнатьєвої, необхідно провести систематизацію законодавства, почавши з удосконалення кодифікованих актів, які займають основне місце в ієрархії цієї системи [7, с. 25].

Ситуація у сфері охорони української природи загрожує національній безпеці, а до числа найбільш вразливих об'єктів необхідно віднести річки, моря, водосховища, озера, болота. Основним кодифікованим актом, на підставі якого проводиться правове регулювання використання, відтворення та охорони вод, $\epsilon$ Водний кодекс України 1995 року, який необхідно вдосконалити з урахуванням досягнень юридичної техніки.

Так, у змісті кодифікованого акту відсутня преамбула, тому необхідно сформулювати зміст цієї частини кодексу. До іï змісту слід включити те, що основним завданням Водного кодексу $є$ поліпшення стану водних ресурсів в Україні, їх раціонального та бережливого використання та охорони, необхідність проводити державно-правову політику, орієнтовану на забезпечення реалізації водного законодавства України, охорону та збереження водного фонду України.

3 авторської точки зору слід доповнити й ст. 1 «Визначення основних термінів» Водного кодексу України. Причиною такого рішення $€$ та обставина, що суб'єктами водних відносин $\epsilon$ водокористувачі, органи державної влади та органи місцевого самоврядування, об'єктами - води (водні об'єкти або їх частини) в межах території України. Виходячи з цього, пропонується закріпити ці елементи водних відносин у ст. 1 кодифікованого акту. Такий підхід $є$ реалізацією концепції Г.Т. Чернобель стосовно необхідності за допомогою юридичної техніки визначити логічні зв' язки, відношення з іншими поняттями [8, с. 80].

3 метою усунення дефектів юридичної техніки автор пропонує доповнити ч. 2 ст. 3 ВК України, в якій слід більш детально викласти такі види підземних водних об'єктів: водоносний горизонт, водозбір підземних вод, артезіанські води, родовище підземних вод, точки природного виходу підземних вод та їх водозборів. На додаток до цього варто внести доповнення стосовно постійного моніторингу підземних водних об'єктів, контролю за їх рівнем у свердловинах, якістю, кількістю небезпечних домішок.

Юридична техніка природоохоронного законодавства повинна виконувати функцію 3 упорядкування впливу людини на екосистему, що знаходить своє відображення в понятті «право водокористування». Ця категорія існує як правовий інститут, а також конкретне право суб'єкта водокористування. До їх числа відносяться фізичні чи юридичні особи, яким в установленому порядку надано право використання водних ресурсів для задоволення власних або комерційних інтересів.

Виходячи з цього, необхідно доповнити ст. 43 ВК «Основні права водокористувачів», до яких належить можливість здійснювати загальне та спеціальне водокористування; використовувати водні об'єкти на умовах оренди; здійснювати інші функції щодо водокористування в порядку, встановленому законодавством. До них необхідно віднести і право на відшкодування збитків власниками водних об'єктів у випадках надання води, яка не відповідає нормам державного стандарту, необґрунтованого зменшення обсягів водопостачання. Як вказує О.М. Краснов, відсутність механізму відшкодування збитків природному середовищу $є$ серйозним дефектом юридичної техніки, тому що не дає можливості ліквідувати наслідки негативних впливів і відновити природне середовище [9, с. 109].

Одним із важливих завдань водного законодавства $\epsilon$ питання охорони водних об'єктів від забруднення, засмічення та вичерпання. Виходячи з цього, пропонується внести доповнення до ст. 95, в якій варто чітко зафіксувати поняття забруднення, під яким розуміється надходження або утворення у водних об'єктах забруднюючих речовин понад встановлені нормативи та вимоги до якості вод. В умовах появи гострого дефіциту водних ресурсів особливої уваги потребує контроль за виснаженням таких об'єктів. Виходячи з цього, ст. 95 повинна бути доповнена роз'ясненням поняття виснаження, під яким розуміється зменшення кількості вод у водних об'єктах внаслідок неправомірних дій або природних процесів, або стихійних явищ, які зменшують до мінімуму можливості самовідновлення водних об'єктів.

Основним завданням юридичної техніки $\epsilon$ знаходження шляхів підвищення якості нормативно-правових актів, які дозволяють регулювати використання та охорону природних об'єктів. Одним із них $є$ рослинний світ, якій має виключну природоохоронну, господарчу, наукову, оздоровчу та рекреаційну цінність. Використання та охорона об'єктів рослинного світу здійснюється на підставі Закону України «Про рослинний світ» 1999 року. Розгляд положень цього кодифікованого акту показує наявність такого недоліку юридичної техніки як недостатня кількість основних термінів, які викладені у ст. 3 закону: рослинний світ, дикорослі рослини, природні рослинні угрупування, акліматизація, інтродукція, об'єкти рослинного світу, природні рослинні ресурси.

Такий перелік $\epsilon$ недостатнім, тому автор пропонує внести доповнення у вигляді таких термінів: баланс озелененої території - відсоткове співвідношення територій, на яких виростають об'єкти рослинного світу. Це поняття відіграє ключову роль у містобудуванні при підготовці генерального плану розвитку міст і населених пунктів, дозволяє визначити зони, які забезпечують реалізацію права громадян на безпечне навколишнє середовище.

До переліку основних термінів варто внести і поняття основних форм зелених насаджень, які виступають в якості елементів навколишнього середовища: бульвар - загальнодоступна упорядкована озеленена територія, розташована між смугами руху транспортних засобів; парк - загальнодоступна упорядкована озеленена територія у населеному пункті; сквер - загальнодоступна упорядкована озеленена територія не значної площі у населеному пункті; ботанічний сад - упорядкована озеленена територія, на якій ростуть деревні, чагарникові, квіткові й інші рослини, які використовуються в науково-дослідних, культурно-просвітницьких і рекреаційних цілях; дендрологічний парк - озеленена територія, на якій ростуть дерева і чагарники, які використовуються в науково-дослідних, навчально-дослідних, культурно-просвітницьких і рекреаційних цілях.

Іншим важливим елементом законодавчих актів $\epsilon$ принципи права, які відсутні в Законі України «Про рослинний світ» 1999 року, який охоплює правовідносини, систему контролю та управління, пов'язану з цим 
питанням. Як вказує Ю.С. Шемшученко, у взаємодію з людиною вступає довкілля, при цьому суспільство пов'язане з природою своїм походженням, існування та майбутнім [10, с. 67]. Виходячи з цього, автор пропонує внести доповнення до змісту цього закону у вигляді окремої статті «Основні принципи в галузі поводження з об'єктами рослинного світу», до яких необхідно віднести принцип законності, згідно якого всі суб'єкти, діяльність яких пов'язана із рослинним світом, зобов'язані точно і безумовно виконувати нормативні приписи. Збереження біологічного різноманіття пов'язане з підписанням ратифікації Україною Конвенції «Про біологічне різноманіття» 1992 року. 3 точки зору охорони таких об'єктів важливе значення мають принципи запобігання шкідливому впливу на зону зростання об'єктів рослинного світу і раціонального, стійкого, бережливого використання цих об'єктів.

У сфері правової охорони природних об'єктів важливу роль відіграють економічні механізми підтримки користувачів природних об'єктів, а також застосування штрафних санкцій для впливу на правопорушників, що може бути закріплено у вигляді певних принципів. По-перше, принцип економічного стимулювання охорони, захисту і відтворення об'єктів рослинного світу, ïx раціонального та невиснажливого використання. По-друге, відшкодування збитків, завданих об'єктам рослинного світу, середовищу їх зростання, життю і здоров'югромадян, майну громадян таюридичнихосіб внаслідок шкідливого впливу на об'єкти рослинного світу.

Рослинний світ має низку специфічних особливостей, до яких належить самовідновлення, поява нових форм і освоєння нових територій. 3 цієї причини до принципів слід включити і врахування особливостей об'єктів рослинного світу при встановленні правового режиму земель або водних об'єктів, в межах яких ці об'єкти рослинного світу виростають.

Одним із завдань юридичної техніки є всебічне охоплення правовідносин і правове забезпечення заходів, пов'язане з ефективним використанням і охороною природних об'єктів. 3 цієї точки зору Закон України «Про рослинний світ» має суттєвий недолік у вигляді відсутності положень стосовно карантину, що дозволяє попередити проникнення і розповсюдження небезпечних шкідників, хвороб і бур'янів, який спрямований на захист рослинних ресурсів. Виходячи з цього, автор пропонує внести до цього закону окрему статтю «Карантин об'єктів рослинного світу», а їі зміст викласти у такій редакції: «Карантин об'єктів рослинного світу реалізується на основі комплексу заходів щодо попередження знищення, пошкодження, погіршення стану таких об'єктів. При проведенні карантину необхідно враховувати біологічні, фізичні, фізіологічні особливості об'єктів рослинного світу та їх функцій. Користувачі земельних ділянок або водних об'єктів з метою реалізації карантинних заходів зобов'язані своєчасно виявляти хвороби і шкідників, дотримуватися технологій, які забезпечують збереження або поліпшення стану таких об'єктів; не допускати поширення шкідників і хвороб об'єктів рослинного світу; надавати допомогу державним організаціям у здійсненні заходів щодо захисту таких об'єктів; своєчасно інформувати державні органи та органи місцевого самоврядування про факти масового знищення або пошкодження об'єктів рослинного світу внаслідок дії шкідників або хвороб».
Ще одним важливим елементом природного середовища $\epsilon$ об'єкти природно-заповідного фонду (далі - ПЗФ), які підлягають використанню, відновленню та охороні. Стосовно таких об'єктів юридична техніка повинна забезпечити збереження їх природного стану та не допустити негативного впливу господарської або інших видів діяльності. Територія України багато років піддавалася ненормованому антропогенному впливу, яке призвело до руйнування значної кількості природних об'єктів. 3 метою їх збереження у 1992 році був прийнятий Закон «Про ПЗФ України», який застарів і вимагає суттєвої переробки, тому автор пропонує внести в текст документа певні пропозиції.

По-перше, доповнити його ст. 2 «Законодавство України про природно-заповідний фонд», яка викладена так: «Відносини в галузі охорони і використання територій та об'єктів природно-заповідного фонду, відтворення його природних комплексів регулюються Законом України «Про охорону навколишнього природного середовища» та іншими актами законодавства України». 3 урахуванням сучасних тенденцій, розвитку природоохоронного законодавства та особливостей юридичної техніки в ньому необхідно зафіксувати відповідність Конституції України. Текст цієї статті автор пропонує викласти в такій редакції: «Правовий статус і охорона об'єктів ПЗФ ґрунтуються на Конституції України та інших актах законодавства, які регулюють відносини у сфері використання та охорони об'єктів. До них належать нормативно-правові акти, пов'язані з охороною і використанням земель, водних об'єктів, тваринного і рослинного світу, надр і лісів».

Особливістю правової політики в сфері ПЗФ України $\epsilon$ несистемний характер підготовки нормативно-правових актів, які часто не відповідають вимогам юридичної техніки, а також відсутність чіткого плану та стратегії. Рішення стосовно створення об'єктів ПЗФ здебільшого приймаються у зв'язку з протестами громадськості, як наприклад при створенні 13.11.2008 року Нижньодністровського національного природного парку, вимогам міжнародних організацій із метою створення екологічних коридорів для міграції птахів і тварин.

Виходячи з цього, до змісту ПЗФ необхідно внести статтю, присвячену питанням знаходження місць розташування, підготовки до створення таких об'єктів під назвою «Планування розвитку природно-заповідного фонду України». До диспозиції цієї статі необхідно внести такі положення: п. 1 «Розвиток об'єктів ПЗФ здійснюється на основі державних, регіональних і міських програм. Загальнодержавна програма розвитку ПЗФ розробляється центральним органом виконавчої влади у сфері охорони природи сумісно з НАН України, іншими державними органами та організаціями. До змісту п. 2 включити таке: «Регіональні схеми розвитку ПЗФ затверджуються обласними, міськими радами депутатів за погодженням із центральним органом виконавчої влади. При їх розробці необхідно враховувати плани, програми, схеми розвитку галузей економіки, сільського господарства, реалізація яких пов'язана з використанням природних ресурсів, які можуть вплинути на такі об'єкти».

Одним із недоліків змісту закону про ПЗФє недостатн $\epsilon$ охоплення питань, пов'язаних із режимом і використанням таких об'єктів. Виходячи з цього, автор пропонує доповнити розділ 9 положеннями, пов'язаними з реалізацією цієї проблеми. В якості назви такої статті пропо- 
нується таке: «Режим охорони та використання ПЗФ». До їі змісту необхідно включити заборону на проведення таких заходів; розвідку і розробку родовищ корисних копалин; скидання стічних вод; мийку механічних транспортних засобів; виконання робіт із гідротехнічної меліорації. До п. 2 статті необхіднл включити заборони на використання юридичними та фізичними особами водними транспортними засобами із двигунами внутрішнього згоряння, рух і стоянку механічних транспортних засобів і самохідних машин поза дорогами загального користування та спеціально обладнаних місць.

В історії України лісовий фонд завжди займав особливе місце. Щодо нього в різні часи приймалася значна кількість нормативно-правових актів. Цей природний ресурс $\epsilon$ національним багатством, тому положення про необхідність охорони природних ресурсів увійшли до розділу VI Декларації про державний суверенітет України від 16.07.1990 року. Відповідно до цього акту народ України має виключне право на володіння, користування i розпорядження iї національним багатством, важливим елементом якого $\epsilon$ лісовий фонд. На прикладі цього природного ресурсу можна дослідити розвиток доктрини, пов'язаний із кодифікацією норм права, що знайшов відображення в Лісовому Уставі, прийнятому у 1880 році. На думку П.І. Лапечук, охорона лісового фонду потребує особливої уваги з боку держи та має бути розширеною за рахунок участі громад в управлінні лісовими ресурсами, що дасть змогу поліпшити використання відходів лісосічного виробництва та неліквідної деревини [11, с. 48].

Правовідносини, пов'язані з цим природним ресурсом, знайшли відображення в змісті Лісового кодексу України, в редакції Закону від 08.02.2006 року. Розгляд положень цього кодифікованого акту показує необхідність включення до нього змісту основних понять, які використовуються в документі. Так, у ст. 1 надані характеристики поняття лісу, лісової ділянки та земельної лісової ділянки.

Незважаючи на те, що ці поняття $є$ базовими в системі лісового законодавства, автор пропонує додатково викласти в тексті цієї статті поняття: 1) ведення лісового господарства - проведення лісогосподарських заходів з одночасним забезпечення раціонального та сталого використання лісових ресурсів; 2) відтворення лісів лісогосподарські заходи, до яких входить вирощування посадкового матеріалу лісових рослин, насінництво лісових рослин, лісовідновлення, лісорозведення та догляд за лісовими насадженнями; 3) дерева головної породи - дерева, які в природних умовах найкращим чином відповідають цілям ведення лісового господарства; 4) деревостій - сукупність дерев, які $€$ основним елементом лісового фонду; 5) природне поновлення лісів - поява нових лісів природним шляхом; 6) лісова продукція - деревина, інші заготовлені, зібрані лісові ресурси; 7) лісокористування - діяльність, у процесі якої використовується лісовий фонд.

Натепер значна кількість лісів України перебуває в оренді у постійних і тимчасових лісокористувачів. Тому удосконалення потребують права постійних лісокористувачів, які займаються заготівлею продукції та другорядними лісокористуваннями. Права та обов'язки постійних лісокористувачів знайшли відображення у ст. 19, але перелік їх прав $\epsilon$ недостатнім з точки зору захисту їхніх інтересів. Автор пропонує внести допов- нення до ст. 19: «Встановлювати і фіксувати факти заподіяння шкоди лісам, висувати претензії до громадян, юридичних осіб, діяльність яких погано впливає на цей природний ресурс, а також звертатися до суду з позовами про відшкодування шкоди лісовому фонду, який знаходиться у їх користуванні». Іншим положенням, яке доцільно внести до ст. 19, є таке: «Обмежувати в разі загрози виникнення лісових пожеж та інших надзвичайних ситуацій відвідування громадянами лісів, в'їзд на територію лісового фонду транспортних засобів, забороняти проведення будь-яких видів робіт».

У зв'язку з тим, що на території Україні практично не залишилося лісів, які не зазнали негативного антропогенного впливу, автор пропонує внести доповнення до ст. 55 «Моніторинг лісів» такого змісту: «Завданням моніторингу $є$ виділення ділянок, які доцільно називати «еталонами» природи, в межах яких заборонено будьякі види природокористування».

Розгляд змісту ЛК України показує, що з точки зору юридичної техніки документ не має повного ланцюга заходів, спрямованих на охорону цього природного ресурсу. Так, у кодифікованому акті вказується про державне регулювання та управління, організацію, введення лісового господарства, відтворення лісів, контроль за охороною, захистом і їх використанням. Виходячи з цього, до змісту закону увійшли статті, в яких регламентуються повноваження посадових осіб державної лісової охорони, але не вказується перелік посад цих посадових осіб. Тому до змісту ст. 90 «Основні завдання лісової охорони» автор пропонує внести доповнення стосовно того, що до посадових осіб цієї служби належать директори, головні лісничі, заступники директорів, лісничі, помічники лісничих, керівники пожежно-хімічних станцій, керівники розплідників, інспектори з охорони природи, старші лісники, лісники, єгеря, контролери.

Висновки. За результатами проведеного дослідження можна сформулювати такі висновки:

1. 3 метою усунення умов, які сприяють появі дефектів, пропонується внести доповнення в зміст базового Закону «Про охорону навколишнього середовища»: а) до ст. 9 у вигляді положень щодо надання державних гарантій прав громадян на безпечне навколишнє середовище та охорону їх здоров'я; б) надати громадським організаціям право створювати природоохоронні фонди без згоди місцевих органів державної влади.

2. Доповнити Водний кодекс України, Лісовий кодекс України, Закон «Про рослинний світ» преамбулами, в яких зафіксувати мету, цілі кодифікаційних актів, а також викласти в них принципи права, які $\epsilon$ основоположними засадами, на підставі яких здійснюється регулювання використання та охорони водних об'єктів, лісів і рослинного світу, забезпечується виконання вимог юридичної техніки щодо конкретності нормативного регулювання.

3. Запропоновано внести доповнення до Водного кодексу України, в якому варто зафіксувати об'єкти водних відносин, органи державної влади та місцевого самоврядування, а також доповнити ст. 43 положеннями щодо права водокористувачів на компенсацію збитків у випадках надання неякісної води і фактів наявності забруднення.

4. 3 урахуванням такої вимоги юридичної техніки як чітке розмежування об'єктів правового регулювання 
В змісті Закону «Про рослинний світ» необхідно закріпити такі форми зелених насаджень як бульвар, парк, сквер, дендрологічний парк.

5. Пропонується реалізувати таку вимогу юридичної техніки як інтегрований підхід шляхом внесення до Закону «Про природно-заповідний фонд України» статтей, у яких викласти засади розвитку об'єктів ПЗФ і включити в іï зміст необхідність підготовки загальнодержавних регіональних програм створення таких об'єктів. На підставі цієї вимоги юридичної техніки до Лісового кодексу України пропонується включити до ст. 1 базові поняття - відтворення лісів, лісова продукція, природне поповнення, що дасть змогу уникнути дублювань і необхідності використання банкетних норм.

\section{Література}

1. Алексеев С.С. Структура советского права. М., 1974. 264 c.

2. Власенко Н.А. Коллизионные нормы в советском праве. Иркутск, 1984. 99 с.

3. Пиголкин А.С. Подготовка проектов нормативных актов (Организация и методика) / Всесоюзный научноисследовательский институт советского законодательства. М. : Юридическая литература, 1968. 167 с.

4. Толкаченко О.В. Право на сприятливе навколишнє середовище в законодавстві України та інших держав. Міжнародна науково-практична конференція «Права людини, національна ідентичність i європейська інтеграція України». 15-16 вересня 2017 року, м. Лодзь, Польща. С. 175-182.
5. Гетьман А.П., Костицький В.В. Екологічні права людини в національній і міжнародній правовій доктрині // Проблеми законності : зб. наук. пр. Харків, 2013. Вип. 124. С. 68-80.

6. Дубовик О.Л. Экологическая информация: понятие, виды, режим, защита // Зеленый мир. 2003. № 21-22. С. 6-7.

7. Игнатьева И.А. Систематизация экологического законодательства: современные проблемы и практические подходы. // Журнал российского права. 2003. № 12. С. 21-29.

8. Чернобель Г.Т. Правовые понятия и их применение в законах // Законодательная техника : науч.-практ. пособ. / Под ред. Ю.А. Тихомирова. М. : Городец, 2000. C. 77-88.

9. Краснов А.Н. К вопросу о путях преодоления дефектов юридической техники экологического законодательства // Методологические проблемы юридической техники. 2007. № 1. С. 106-110.

10. Шемшученко Ю.С., Костицький В.В. Про соціальну обумовленість сучасних проблем теорії та методології екологічного права // Екологічне право України. 2017. № 1-2. С. 66-74.

11. Лапечук П.І., Попович Т.Г. Кодифікація екологічного законодавства України на тлі децентралізації влади // Екологічне право України. 2016. С. 47-50.

Патлачук О. В., кандидат юридичних наук, викладач

Краматорського економіко-гуманітарного інституту 